\title{
METHODS OF TESTING IDEAS IN THE PROJECT "VILLAGES ON MOVE BALTIC": EXPERIENCES FROM BALTIC COUNTRIES
}

\author{
Viktorija Piščalkienė ${ }^{1}$, Milda Gintiliené ${ }^{1}$, Donatas Misiūnas ${ }^{1}$, Vilma Rasteniené ${ }^{1}$, \\ Marita Mattilas, Petra Muraus ${ }^{3}$, Mari Kurtti³, Helen Kool², Jaana Siik ${ }^{2}$, \\ Regitze Kristensen ${ }^{6}$, Anita Selicka ${ }^{4}$ \\ ${ }^{1}$ Kaunas College / University of Applied Sciences, Lithuania, ${ }^{2}$ Lääne-Viru College, Estonia, \\ ${ }^{3}$ Southern Savo Sports Federation, Finland, ${ }^{4}$ Latvian Rural Forum, Latvia, \\ ${ }^{5}$ South-Eastern Finland University of Applied Sciences, Finland, \\ ${ }^{6}$ Lillebaelt Academy / University of Applied Sciences, Denmark
}

Key words: physical activity, leisure, recreation, project „Villages on Move Baltic“.
Summary
Physical activity is considered as an important tool for promoting of public health. Studies have shown connections between physical activities and mental and physical health, as it is one of the evaluating fac- tors of community indicators. It is recommended that community sport participation is advocated as a form of leisure time for children and adolescents, in an effort to not only improve physical health in relation to such matters as the obesity crisis, but also to en- hance psychological and social health outcomes. One of the project "Villages on Move Baltic" (VOMB) 1.1.2016-31.12.2017 (Number 2016-3715/001-001) objectives is to focus more on Health Enhancing Phy- sical Activity and joy of sports for rural citizen in participating regions.
This article covers the reasons for seeking to increase participation in sport and other physical recreation activities: health and social engagement; lifestyle, everyday attraction and tourism opportunities.
"Villages on Move Baltic" project is activating people to give ideas on how to promote everyday physical activity and how to organise their leisure time in rural areas. The collected ideas are developed by means of culture of experimentation. The Project's participants have visited village events and have promoted healthy lifestyle. The goal is to activate inhabitants in rural areas to have more movement and more joy of sports. The ideas about the desirable and interesting forms of physical activity among the rural population were gathered within the participation in 40 events of "Vil-

lages on Move Baltic" project (VOMB). A total number of participants is 2030, which provided 830 ideas related to physical activity in everyday life and in various events.

Conclusions: A great number of ideas about physical activities were collected using verbal and non-verbal methods such as physical activity exercises or games, structured interviews, writing ideas, discussion and drawing. The idea is that competition methods should be applied to specific age and culture groups.

\section{Introduction}

Recreation with cultural and artistic part, leisure and physical activities are playing an important role in urban and in rural areas communities. Individuals, families, small groups, teams or the whole urban / rural community may be involved in recreation, leisure or sports activities. Everyday promoting of any kind of physical activity is relevant to people of all different ages, abilities and levels of skills. This includes a multitude of useful benefits such as improving the health and well-being of individuals, providing joy of sports, contributing to the empowerment of individuals. According to local context the types of physical activities vary greatly and reflect the social systems and cultural values [6].

Participation in active everyday life sometime is unavailable for people with limited capabilities, for example, for people with physical disabilities, refugees.

Why should we be seeking to increase participation in More Health Enhancing Physical Activity? Participation in More Health Enhancing Physical activities can have many benefits for both parties; the individuals and community. Disease prevention and health promotion- recreation and sports activities are enjoyable and is effective way to improve health and well-being; they can relieve stress, increase fitness, im- 
prove physical and mental health, and prevent development of chronic diseases, such as heart diseases. Participation in sport and physical recreation can help to reduce the incidence of overweight and obesity. Almost 1 adult in 6 in the EU is considered obese [11]. Regular physical activity reduces risk of cardiovascular disease, thromboembolic stroke, hypertension, type 2 diabetes mellitus, osteoporosis, obesity, colon cancer, breast cancer, anxiety, and depression [8]. The study of mental health and well-being has received great impulse during the last two decades, through theories and empirical models deriving from two complementary perspectives [10]. On other hand, satisfaction with life is primarily predicted by disease severity and social support in one study [9].

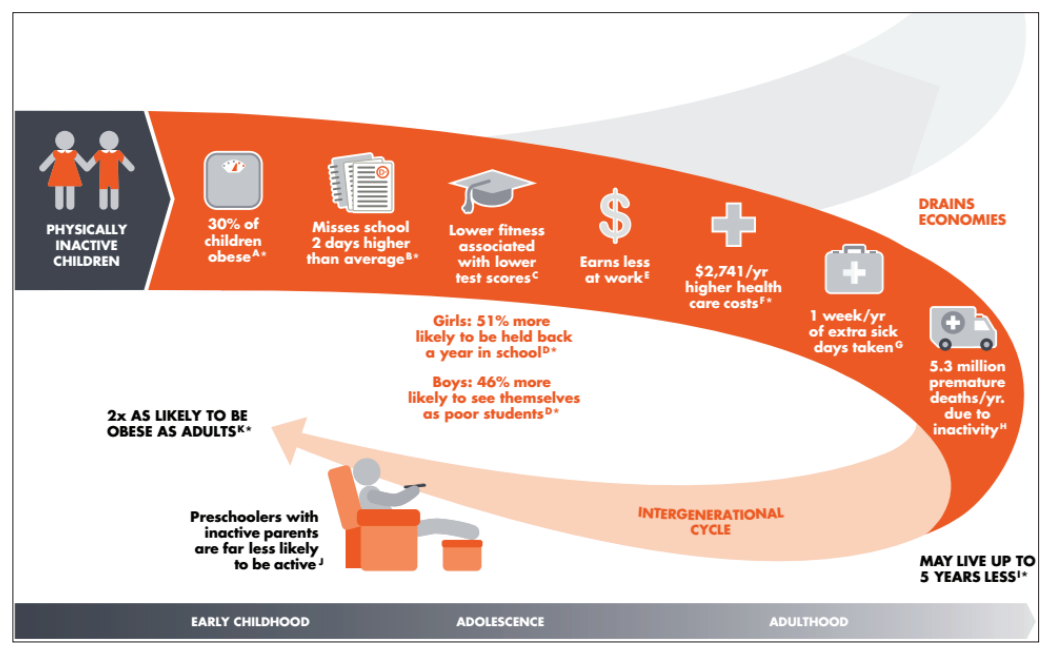

Figure 1. Nike, Inc. (2012), DESIGNED TO MOVE: A Physical Activity Action Agenda. (https://clubs.marathonkids.org/keeping-kids-moving/)

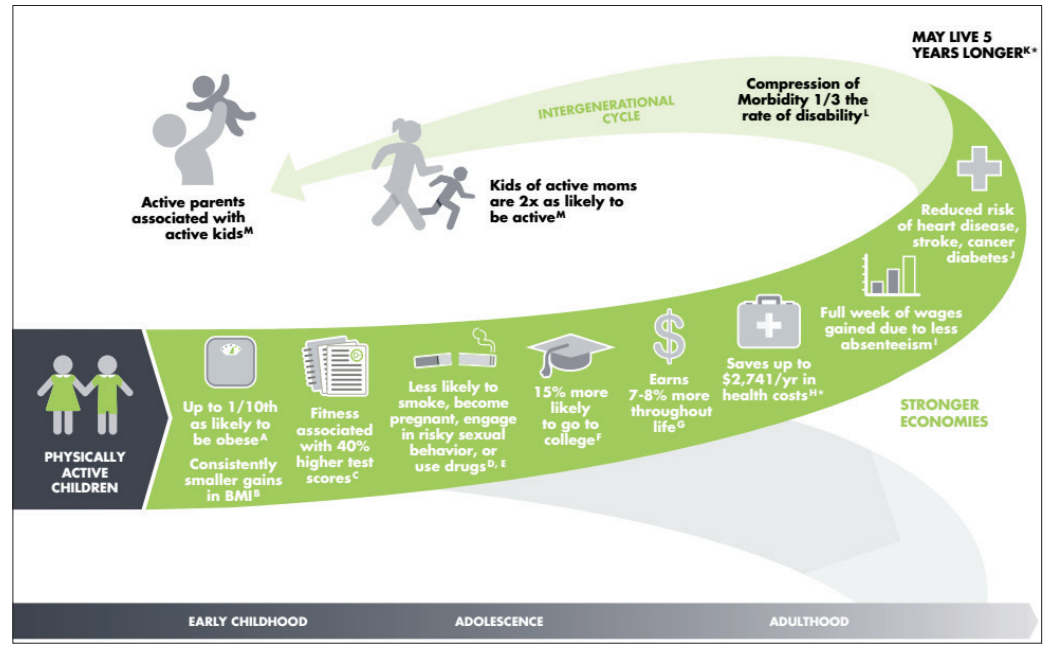

Figure 2. Nike, Inc. (2012), DESIGNED TO MOVE: A Physical Activity Action Agenda. (https://clubs.marathonkids.org/keeping-kids-moving/)
Capacity building - physical and social skills are some of the many skills that can be developed through participation in recreation and sports activities. Even a conceptual model, Health through Sport, was proposed [3]. The model depicts the relationship between psychological, psychosocial and social health domains, and their positive associations with sport participation, as reported in the literature.

Public information, reduction of social inclusion - recreation and sports activities are a powerful, low-cost means to foster greater inclusion of people with disabilities, as it is said in Convention on the Rights of Persons with Disabilities [1]; they bring people of all ages and abilities together for enjoyment, and provide people with disabilities the opportunity to demonstrate their strengths and abilities, and promote a positive image of disability. Well-being is a dynamic growth process, that includes a wide range of constructs such as goal setting and pursuit, meaning-making, self-expressiveness, self-determination, selfacceptance, skill development and mastery, trust in relationships, and social integration $[5 ; 7]$.

Sport as universal language can be used as a powerful tool to promote peace, tolerance and understanding by bringing people together across boundaries, cultures and religions.

The Aim of article is to reveal methods of testing ideas in the project "Villages on Move Baltic".

\section{Material and methods}

As former New Zealand middle-distance to long-distance runner Rodney Phillip says in his presentation, Physical Inactivity is a Deadly Cycle. As former New Zealand middle- to long-distance runner Rodney Phillip says in his presentation, Physical Inactivity is a Deadly Cycle. As children head into adolescence, they draw the blueprints for their adult lives. Not just their adult bodies, but their adult intellect, character, emotional resilience and social skills. Lower physical activity levels higher intergenerational cycle development of fundamental movement skills for foundation of physical activity. (Fig. 1).

Access to active and healthy lifestyle opportunities will attract new families to regional areas, and provide reasons for others to join (Fig. 2).

Sporting and physical recreation associated with tourism activities can also increase 
income and employment opportunities for local businesses incomes what could support more health enhancing physical activities.

According Khasnabish et al., 2010, activities are successful when they are: requested by individuals and communities, culturally appropriate, enjoyable and fulfilling for participants, and not too costly to develop and sustain.

It is scientifically acknowledged that participating in regular physicaly active leisure is highly beneficial for both physical health and psychological wellbeing. Why do people choose to participate in sport and physical recreation? Molanorouzi and coauthors (2015) in their study examined whether motives for participation could accurately discriminate gender, age, and type of physical activity. The results of this study highlighted that understanding strong participation motives across type of activity, age, and gender may be effective in promoting physical activity for adults. According to other findings [4] being with friends, having fun, living adventurously, and enjoying competitive challenges become less potent motivators for exercise as one ages.

The reasons why do people choose to participate in sport and physical recreation could be classified according to par-

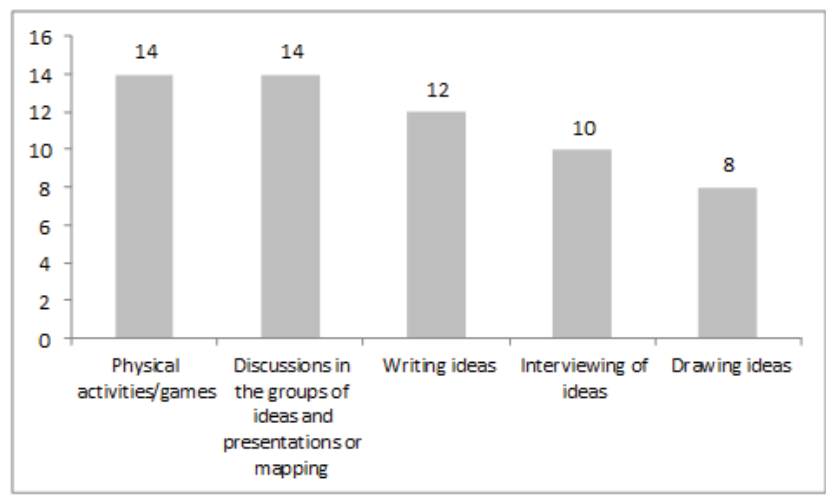

Fig. 1. Methods of collecting ideas in the events and meeting

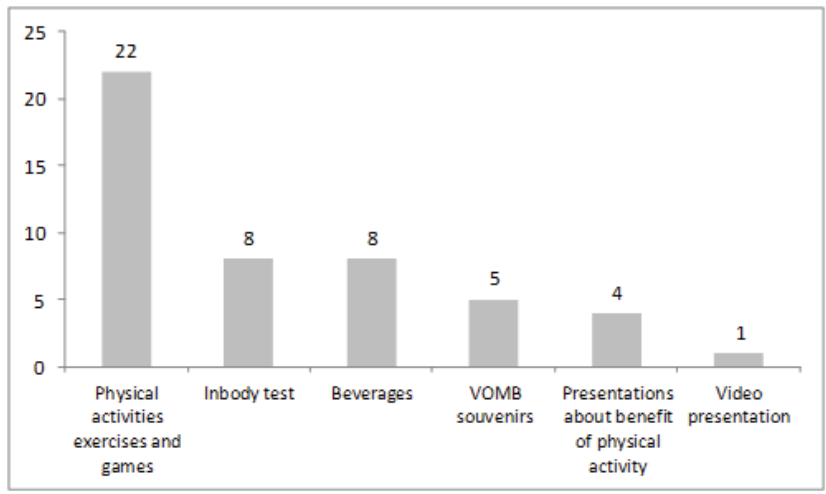

Fig. 2. Used motivation forms for the collecting ideas in the event and meetings ticipating or not in active leisure.

Of those who participate in sport and physical recreation: $33 \%$ have indicated that they do so for health and fitness; $21 \%$ for enjoyment; $16 \%$ for well-being; and $14 \%$ for social or family reasons.

In contrast, of those who do not participate: $45 \%$ indicated that they had insufficient time due to work or study; $18 \%$ were "not interested"; and 17\% indicated that they had insufficient

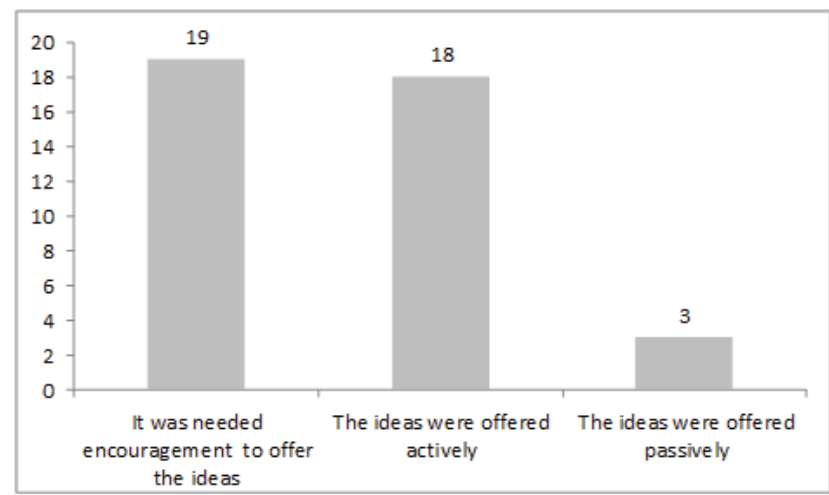

Fig. 3. The attitudes of the participants to collecting ideas

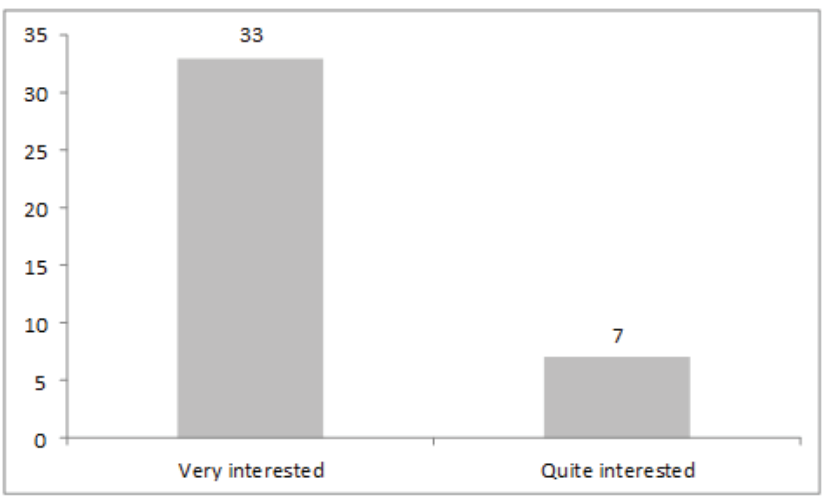

Fig. 4. Organizers of events or heads /staff interest in our participation in the events

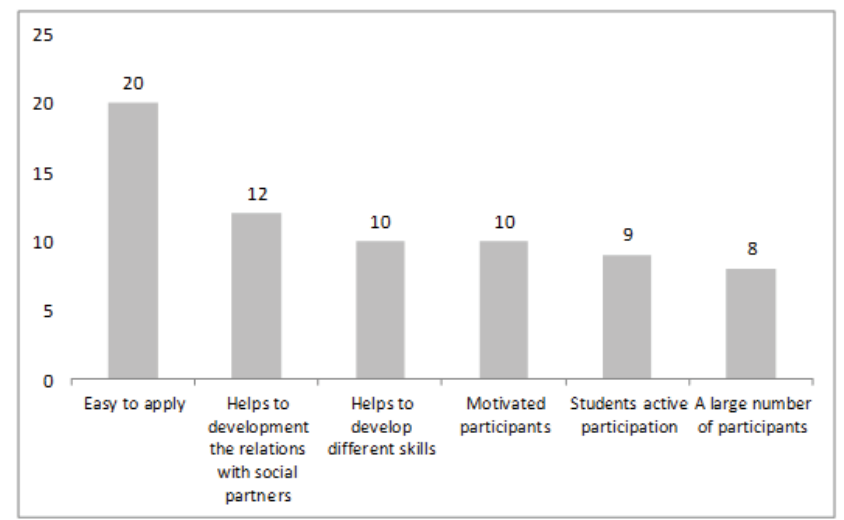

Fig. 5. Advantages of the used idea collection methods in the events 
time due to family commitments [6]. It was found that two factors, toned, fit and stress reduction, revealed higher motivation scores with increasing age, while mental toughness and fun and friends, were oposite with increasing age [4].

Information about idea competitions events and meetings. The ideas about the desirable and interesting forms of physical activity among the rural population were gathered within the participation in 40 events/meetings/activities of "Villages on Move Baltic" project (VOMB).

Below is a presentation of the events and countries in which the VOMB project's lecturers, students and project staff took part in the period from February 2017 to February 2018.

Finland

- Idea competition with immigrants and refugees, South Savo vocational college, Mikkeli and Petunmaa. Finland (14).

- "Everybody is dancing", Finland, Mikkeli.

- Luonteri Pyöräily event, Anttola, Mikkeli.

- Idea competition with kids in afternoon club, Urpola school, Mikkeli.

- Idea competition with kids in afternoon club, Rouhiala school, Mikkeli.

- Finland Ice marathon, Finland, Kuopio.

Lithuania

- Idea competition, Lithuania, A. A. Kriauzu primary school in Raudondvaris.

- Ideas competition-Active seminar introducing project. Lithuania, Kaunas University of Applied Sciences, Faculty of Medicine.

- Sport event for faculty of Medicine students, Kaunas University of Applied Sciences, Faculty of Medicine.

- Sport event for disabled people, Kaunas District Municipality Center of Social Services.

- Village celebration in the Raudondvaris Castle, Raudondvaris .

- "Healthly family Day" (Rukla), Rukla.

- Kite Festival "Between Earth and Sky", Zapyskis.

- Camp for people who have Parkinson disease "Selfexpression and healthy movement", Kaunas University of Applied Sciences, Faculty of Medicine.

- Racing competition in Kacergine, Kacergine.

- Idea competition - Seminar for people who have osteoporosis from Association "Rock/Uola", Kaunas University of Applied Sciences, Faculty of Medicine.

- Idea competition at Gym club "DonnyGym", Raudondvaris.

Denmark

- Ideas competition - Summer games, Odense.

Estonia

- Idea competition, Uhtna.

- Idea competition, Modriku (3).
- Idea competition, Rakvere.

- Idea competition, Tallin.

- Idea competition, Rakvere, central library.

- Idea competition, Haljala.

The participants of idea competition events and meetings. The ideas were gathered in different age groups. During the public events, not only adults, but also children participated. In order to modify, make an interesting collection of ideas for the age group of children participants were going to specially organized events or educational institutions. The idea of the research project is to involve people of all ages, not only adults, but also elderly people with different disabilities. That's why elderly people took part in elderly events or we have organized by ourselves activities in their own institutions, for example events for Parkinson's disease or osteoporosis patients in Kaunas University of Applied Sciences. One of the target group in the VOMB project are refugees and immigrants. Therefore, part of such meetings involving them in various types of physical or social activities took place in Finland (12 events) and Lithuania (1 event). Children's ideas were collected through participation in 9 targeted events only for children and teens. 31 events were executed for adults, some of which were devoted to a mixed group of children and adults. There were 4 events or activities executed only for seniors.

Information about the persons producing and collecting ideas. A total number of participants is 2030, which provided 830 ideas related to physical activity in everyday life and in various events.

Students, lecturers and project participants participated in organizing the collection of ideas at various sports and educational events. To summarize, only $1 / 3$ of the events dedicated to the idea competition were not attended by students. Most of them participated in two. However, there were events such as Kite Festival (Lithuania), where they were attended by eight students. Participation of students in events contributed to strengthening volunteering in specific situations, in dealing with people from different social backgrounds, engaging in various social activities and participating in inbody tests and conducting research applied in their physical activity in everyday life. Project "Villages on Move Baltic" staff - lecturers and project promoters participated in all events, organizing job before and after events, maintaining feedback with the event organizers and the administration of the institutions.

The collection of ideas by participating in various events took an average of 2.8 hours, but there were a number of such visits at events where the time spent was 6 hours or more.

Results of the study of idea competition

A great number ideas about physical activity opportunities 
for rural residents that can be organized indoors and outdoors were collected using verbal and non-verbal methods. Verbal methods that promote the development of social skills were used in group discussion. This organizational approach can be applied in smaller groups. Therefore, it did not apply to major events involving a large number of participants. The workgroups process was organized and coordinated by the VOMB project staff or students involved in this project. The final result of group discussions was presented during oral presentations or by posting on the map disputed information.

As the main idea behind the VOMB project is to promote physical activity in everyday life, the ideas were gathered by integrating various forms of physical activity, not only indoors but also outdoors. The ideas were also collected in writing (12 events or meetings) during the interview. This method was applied during major events and allowed to get ides more faster. Drawing of ideas was applied as one of the creative methods. The method has the ability to develop general skills, encouraging the participants to express their thoughts. It was used 8 times at smaller events and meetings. This method has mostly been used in children's groups and has been seen as an effective and stimulating the interest of children in understanding the benefits of physical activity and even assessing themselves in these activities (Fig.1).

Due to the opinion of VOMB project lecturers and staff, the integration of various physical activities into the collection of ideas was successful and as activating form for various age persons. There were choosen nordic walking, football, gym, bowling, exercises, games for adults and kids or younger generation as a supplementary motivational activity in more than half of the events (Fig. 2). Inclusion of different age groups in various forms of physical activity - children, mostly games, adults and elderly people, various indoor and outdoor exercises. Different age groups were involved in various forms of physical activity. Children were involved mostly in games, adults and elderly people in various indoor and outdoor exercises. A very motivating tool was to involve children and adults in testing their invented games (own ideas).

According Figure 3, participants shared their own ideas only in half of the events and meetings. It was not noticed difference in activity in multicultural aspect during these meetings. Thus, it can be assumed that there are certain traits of participants passivity. In the future, further applied reseach can be done and a deeper analysis of specific causes that may be cultural, motivational, personal. (Fig. 3).

Event organizers had positive point of wiev on cooperation with the project team. This could have been affected by previuos cooperation links with institutions participating in the project. It seems that cooperation improved a quality of the events. In 7 events (out of 40) we noticed that we were partially interested in our participation. Most often, we participated (30 out of 40) in those events where our organizations have close links and are already engaged in joint activities (Figure 4).

The methods used to collect the ideas were grouped into 6 groups (Fig. 5). At 20 events the methods featured an easy application. An important aspect was the fact that we managed to develop contacts and cooperate with the social partners. The motivation and opportunity for the participants to develop various skills were mentioned as an advantage (project teachers and employees had physical capacity and social skills in mind). The active participation of students in our educational institutions was also seen as an advantage in collecting ideas. A large number of participants was also an important factor in collecting ideas, since it allowed them to gather more ideas from various events.

In terms of disadvantages, it would be like to mention the cultural differences which restricted the collection of ideas, because of the participation of different nationalities in the groups of refugies and immigrants. In these groups language problems were emerged as a factor influencing the smaller collection of ideas. Only in very rare cases was the lack of involvement of participants or unclear perception of the task, high noise, and cold weather.

Below are some collecting methods of ideas that can be applied to specific age groups, such as drawing for children, discussions for adults and for smaller groups. But their good feature is good communication and knowledge of the language that is being discussed in that group of people. Physical activity forms, as motivational and idea collection methods, can be applied in different age groups. It's just important to remember that exercises, games must match the physical fitness of that age group and should be attractive and motivating.

\section{Conclusions}

1. A number of ideas about physical activity opportunities that can be organized indoors and outdoors were collected using verbal and non-verbal methods such as physical activity exercises or games, structured interviews, writing ideas, discussion and drawing.

2. In the opinion of the VOMB project's lecturers and staff, the integration of various activities of physical activity into the collection of ideas was a successful and a form of activation for various ages.

3. The organizers of the events positively took into account our participation there. Our project promoters believe that our work is interesting and useful in improving the organization and quality of events.

4. The applied methods for collecting ideas were easy to apply. An important aspect was the fact that we managed 
to develop contacts and cooperate with the social partners. The motivation and opportunity of participants in the event to help them develop social skills and physical capacity was mentioned as an advantage.

5. Cultural differences somehow restricted the collection of ideas because of the participation of different nationalities in the groups of refugees and immigrants. In these groups language problems raised as a factor influencing the smaller collection of ideas.

6. Idea competition methods should be applied to specific age groups, such as drawing for children, a method of discussion in a small group of adults or children. Physical activity forms, as motivating and idea collection method, can be applied in different age groups.

\section{References}

1. Convention on the Rights of Persons with Disabilities. United Nations. https://www.un.org/development/ desa/disabilities/ convention-on-the-rights-of-persons-with-disabilities.html. 13 December 2006. Accessed April 112018.

2. Delle Fave A, Bassi M, Allegri B. et al. Beyond disease: happiness, goals, and meanings among persons with multiple sclerosis and their caregivers. Frontiers in Psychology 2017;8:2216. doi:10.3389/fpsyg.2017.02216.

https://doi.org/10.3389/fpsyg.2017.02216

3. Eime RM, Young JA, Harvey JT, Charity MJ, Payne WR. A systematic review of the psychological and social benefits of participation in sport for adults: informing development of a conceptual model of health through sport. Int J Behav Nutr Phys Act 2013;10:135.

https://doi.org/10.1186/1479-5868-10-135

4. Gavin J, Keough M, Abravanel M, Moudrakovski T, Mcbrearty M. Motivations for participation in physical activity across the lifespan. Int J Wellbeing 2014;4(1):46-61.

https://doi.org/10.5502/ijw.v4i1.3

5. Huta V, Waterman AS. Eudaimonia and its distinction from hedonia: developing a classification and terminology for understanding conceptual and operational definitions. J. Happiness Stud 2014; 15:1425-1456.

https://doi.org/10.1007/s10902-013-9485-0

6. Khasnabis C, Heinicke Motsch K, Achu K. et al. Communitybased rehabilitation: CBR guidelines. Geneva: World Health Organization 2010

7. Molanorouzi K, Khoo S, Morris T. Motives for adult participation in physical activity: type of activity, age, and gender. BMC public health 2015;15:66.

https://doi.org/10.1186/s12889-015-1429-7

8. Nelson ME, Rejeski, WJ, Blair SN, Duncan PW, Judge JO, King AC. Castaneda-Sceppa, C. Physical activity and public health in older adults: recommendation from the American College of Sports Medicine and the American Heart Association. Circulation 2007;116(9):1094-1105.
https://doi.org/10.1161/CIRCULATIONAHA.107.185650

9. Ryan KA, Rapport LJ, Sherman TE, Hanks RA, Lisak R, Khan $\mathrm{O}$. Predictors of subjective well-being among individuals with multiple sclerosis. Clin Neuropsychol 2007;21:239-262. https://doi.org/10.1080/13854040600582460

10. Soyeon Ahn, Alicia L. Fedewa. Meta-analysis of the relationship between children's physical activity and mental health. Journal of Pediatric Psychology 2011;36(4):385-397.

https://doi.org/10.1093/jpepsy/jsq107

11. The Europe explained. Food safety. 2014 europa.eu/europeanunion/file/1280/download_en? token=AEdF-HZA Accessed April 112018.

\section{IDE்JŲ TESTAVIMO METODAI PROJEKTE „VILLAGES ON MOVE BALTIC": BALTIJOS ŠALIŲ PATIRTIS}

V.Piščalkienė, M.Gintilienė, D.Misiūnas, V.Rastenienė, M.Mattila, P.Muraus, M.Kurtti, H.Kool, J.Siik, R.Kristensen, A.Selicka

Raktažodžiai: fizinis aktyvumas, laisvalaikis, rekreacija, projektas „Villages on Move Baltic“.

Santrauka

Vienas iš veiksnių, skatinantis gerą savijautą, yra fizinis aktyvumas. Fizinis aktyvumas turi teigiamą poveikị fizinei ir psichinei sveikatai. Bendruomenės veiklos prioritetuose turètų būtų skiriama daug dèmesio vaikų, paauglių, suaugusių asmenų dalyvavimui ịvairiose aktyviose fizinio pobūdžio veiklose, kurios būtu patrauklios socialiniu, kultūriniu, sportiniu požiūriu ir atitiktų amžiaus, socialiniu grupių poreikius. Kaimo ir nedidelių miesteliu gyventoju aktyvumą skatinantis projektas prisideda prie įvairių formų fizinio aktyvumo igyvendinimo ir kultūrinio eksperimentavimo Baltijos šalyse - Lietuvoje, Latvijoje, Estijoje, Danijoje, Suomijoje.

Straipsnyje atskleisti metodai, kurie buvo taikomi renkant idejjas apie fizinio aktyvumo veiklas projekte „Villages on Move Baltic“.

Informacija apie projekte dalyvaujančių šalių gyventojų fizinio aktyvumo idéjas buvo renkamos dalyvaujant renginiuose (40). Šiuose renginiuose dalyvavo apie 2030 žmonių, kurie išsakè nuomonę apie jiems ịdomias ir patrauklias fizinio aktyvumo veiklas.

Išvados. Idejjos apie fizinio aktyvumo veiklas buvo renkamos naudojant verbalinius ir neverbalinius metodus. Verbaliniai - diskusijos, struktūruotas interviu, „Idèjų lietus“ ir kt. Neverbaliniai - fiziniai pratimai ir mankštos, idejju piešimas, rašymas ir kt. Fizinio aktyvumo idejjų rinkimo paieška turètų būti orientuota ị konkrečias amžiaus ir kultūrines grupes.

Adresas susirašinèti: viktorija.piscalkiene@go.kauko.lt

Gauta 2018-04-26 